\title{
Deregulation of laws and border facilitations, and their impact on the increase of competitiveness of Polish seaports
}

\author{
Magdalena Adamowicz ${ }^{1}$ *, \\ ${ }^{1}$ University of Gdansk, PhD, Maritime Law Department, Faculty of Law and Administration, Poland
}

\begin{abstract}
This article attempts to explore the effects caused by the implementation of facilities for maritime entrepreneurs introduced under the act deregulating economic law (hereinafter: "Ports 24h" or port package). Moreover it was analysed whether the procedures implemented by the Customs Service and border units, and in particular the simplified procedure, one stop shop and single window, shortened the time of customs clearance in ports. It was examined whether new solutions affected seaports in Poland and helped to build their competitive advantage over the Baltic Sea. The port of Gdansk was particularly interested due to the annual increase in transhipments. There is a surprising lack of studies on customs conveniences in sea ports. The bulk of academic work focuses on the competitiveness of sea ports as seen through infrastructural investments, with no consideration given to factors such as stable, clear and reliable law which does not impede enterprises in their business.
\end{abstract}

\section{Introduction}

Access to the sea and the possession of well-developed sea ports count among the determinants of economic growth for every country. It is commonly believed that a sea port is a window to the world [1].

In Poland, just as in many other countries of the world, sea ports are a critical ingredient of and a major influence on the operation of the economy. If favorable conditions exist for sea ports to develop and operate efficiently, the entire economy is at an advantage, while any barriers or negative factors have a detrimental impact on the economy of any country. It is very important therefore to provide sea ports in Poland with opportunities for action in order not only to clear hurdles to their growth but also to enable their development and progress to the position of leaders in the Baltic area.

It was only a few years ago, in 2012, that one, in 2012, one of the world's leading consulting companies produced a report which found that Polish sea ports would have to face numerous challenges that slow down their development at present [2]. Among said barriers were issues related to VAT payments, unreasonably long customs procedures and problems with obtaining necessary documents as quickly as in the Western ports. The report estimated that 670000 TEUs worth of traffic arriving at or departing from Poland

*Corresponding author: madamowicz@prawo.ug.edu.pl 
was handled by other than Polish ports, [2] with ineffective customs, taxation and sanitation procedures at border checkpoints provided as the reasons.

Similar criticisms and postulates came as early as 2004 before Poland's accession to the European Union from various environments, including importers, exporters, freight forwarders, carriers, terminal operators and even customs authorities themselves, calling for reform in relevant legal regulations. The need for new solutions followed not only from trends in nation-wide policies intended to introduce facilitations for entrepreneurs, but also from the necessity to implement procedures consistent with solutions adopted in the EU member states and around the world. It was predicted that new solutions in this field, once implemented, would enable a substantial volume of cargo traffic to be re-directed towards Polish ports. To that end, preparations were started to set up indispensable conditions in Poland to create the Baltic logistics and transport centre for Central and Eastern Europe. For such an ambitious project to become a reality, however, a number of legal and organizational changes would have to take place, including facilitations for entrepreneurs, modernization of the existing and construction of new road, rail and port infrastructure on land and water alike. Another barrier to increasing the volume of cargo is posed by shortcomings in the IT system and an inadequate exchange of information and documents by electronic means, as well as system incompatibility among various administrative authorities and between the same authorities and entrepreneurs.

Not only will this article attempt to explore the legal effects of facilitations for entrepreneurs introduced within the framework of the 4th deregulation act, [3] the so-called "Ports $24 \mathrm{~h}$ " packet and procedures implemented by state administrative bodies (e.g. the Customs Service), but it will also determine their impact on sea ports in Poland building their competitive edge, with special reference being made to the Sea Port of Gdańsk. Due to size constraints, the present article will omit any issues related to infrastructural investments at the ports and in their vicinity as well as broadly understood digitization, as the foregoing have been discussed extensively in the literature [4,5].

\section{EU policy on facilitations in processing ships at sea ports}

EU Directive 2010/65 on reporting formalities for ships, which entered into force in 2015 [6], obliged all member states to implement appropriate domestic regulations. Its goal was to simplify and harmonize administrative procedures applied in maritime transport by making electronic transmission of information standard and rationalizing reporting formalities. The Directive applies to ships entering and departing from ports situated in member states.

The Directive made provision for the so-called "single window", or a single place of storage of all data concerning sea-going vessels and cargo. The idea was that information would be reported and collected in one place to be shared with all authorized institutions involved in ship's clearance, i.e. coast guard, veterinary, sanitary and customs authorities as well as other authorized [7]. The aim of the legislation was for ships arriving at ports to transfer all the necessary data to the relevant domestic authority and be processed even before mooring. Any in-port checks by customs services or other officials would then be carried out on an ad-hoc basis only.

Another goal of the directive was to create a uniform internal market which would despite the elimination of cross-border controls - ensure safety for inhabitants and the environment. Poland as a border state of the EU was tasked to cause its customs services to allow goods brought from outside the EU into free circulation in such a way as to comply with safety standards for all users and the environment. 
To ensure standardized clearance and processing for ships at the international level and because of the global dimension of maritime transport, EU legislation, including the present directive, had to take into account the requirements of the International Maritime Organization (IMO) [8]. Therefore, the Directive obliged member states to adopt harmonized and updated forms (FAL forms) prepared by the IMO in the FAL Convention in order to facilitate traffic [9]. However, compliance with reporting requirements by completing the paper versions of FAL forms was acceptable only until 1 June 2015, with electronic documents being the only permissible form from then onwards.

Besides, the Directive obliged member states to extend cooperation between the competent authorities, such as the authorities responsible for customs, border checks, and public health and transport, to simplify and harmonize reporting formalities in the EU and rationalize their use of electronic data transmission and data exchange systems, while also removing barriers in maritime transport and creating a European maritime transport area without barriers.

\section{The "Port Packet" - reasons for revision}

The foregoing EU Directive on reporting formalities for ships was one of the principal reasons for introducing the changes in our national system of customs and border clearance procedures at sea ports.

Another reason for the changes stemmed from the fact that customs procedures at Polish sea ports took too long a time in comparison with their Western counterparts. Clearance procedures were subject to overly long verifications involving a great deal of red tape. Imported goods, especially food, were subject to control by specialized bodies such as the Customs Service, Veterinary Inspectorate, State Sanitary Inspectorate, Inspectorate for the Commercial Quality of Agricultural and Food Products, State Inspectorate for the Protection of Plants and Seeds. Each of these bodies was authorized to carry out mutually independent checks. There was no coordination between the activities of the individual bodies and those of the mentioned authorities. Before 2015, a delivery was subject to checks by more than one authority and so it had to undergo the same logistical operations a number of times, resulting in a long handling time and increased costs for entrepreneurs. If the authorities had acted jointly, the checks could have been carried out more quickly than when each of them was performed separately. The average waiting time at a Polish sea port prior to enacting the legislation was 30 hours and - in earlier times - 5 days, a week or even longer. In Western European ports, the same process took from 1 to 2 days, allowing importers to save time and money [10].

The main reasons for long and costly procedures at ports before enacting the legislation included:

(1) The absence of communication between the respective links in the supply chain and control bodies at ports.

(2) The absence of precise pre-arrival cargo information which could be used for risk assessment, identification of the goods and of the transacting parties.

(3) Multi-stage risk assessment.

(4) Insufficient technical and organizational measures at the disposal of port operators.

(5) The absence of mutual cooperation between the inspectorates, especially when drafting and issuing post-control decisions, due to a long response time. 
Other relevant factors include: a) insufficient working time of the inspectorates and frequent delays in the issuance of decisions; b) unequal level of digitization of the inspectorates, limiting the possibility of a quick exchange of information; c) discrepancies in the internal procedures of each of the inspectorates with regard to control and issuance of decisions, d) organization and work conditions - some of the inspectorates do not have their offices at container terminals and their officials have to commute.

Therefore, a discussion sprang up around issues related to customs and general difficulties in the access to Polish sea ports as well as near-discriminatory legal provisions giving preference to German and Dutch sea ports over Polish ones. In the discussions, it was said that the largest "Polish" cargo-handling port was Hamburg rather than Szczecin, Gdynia or Gdańsk. Unsurprisingly, such issues underlie persistent complaints of Polish entrepreneurs about administrative bodies and port operators. The parties concerned together with representatives of the government signed a declaration of intent entitled "The Polish Gate - The Polish Ports", whose signatories undertook to take joint action to amend the discriminatory laws as they now stand. The idea proposed is that cargo arriving by sea should be cleared by the Customs Service and arious inspectorates within a reasonable time-limit to fast-track procedures and improve the competitive position of Polish sea ports.

Another problem is VAT settlement. The EU has in place a cashless VAT system that eliminates the need for entrepreneurs to reserve additional funds to cover VAT payments, with deferment periods of up to 90 days. Poland adopted a similar solution in 2012, but it requires posting a large deposit, which means that only 5 to 10 per cent of forwarders qualify. Therefore, it is cheaper for forwarders to choose the port in Hamburg or Rotterdam, as this does not necessitate any additional funds. Multitude of inspectorates, control institutions is Is yet another issue.

\section{3. "Port 24h" implementation}

On 1 January 2015, the Act on Facilitating Business Activities of 7 November 2014 came into force. It imposed a 24-hour time-limit for completing any formalities related to the carriage of goods by sea, counting from the time of their declaration at customs. The Customs Service was tasked to coordinate inspections at ports in such a way as to ensure that all inspection activities are carried out with the least possible inconvenience to importers and operators. Under the coordinating efforts, the Customs Service was obliged to:

1) inform the authority competent under separate regulations to carry out inspections of goods brought from third states of the arrival in the EU customs area of goods subject to obligatory inspection carried out by that authority;

2) set a time, date and place of inspection of goods brought from third states in coordination with the port operator and holder of the goods.

The 24-hour time-limit did not apply to cases requiring laboratory tests, quarantine or - in the case of livestock transports - isolation. In all other situations, the duration of inspections at the port, including those carried out by the Customs Service, of goods brought by sea from third states should not exceed 24 hours, as counted from declaration at customs, filing a complete inspection application form with the proper authorities and providing notice of the time and place of inspection until the release of goods.

Therefore, the 24-hour time-limit begins to run when all of the requirements have been met, i.e. declaration of goods, filing the paperwork and setting a time and place of inspection.

The Customs Service can carry out the task thanks to an exchange-of-data system (Inspection Coordination System - ICS) implemented to bring together other border control 
bodies and entrepreneurs. ICS replaces paper documents and allows progress tracking on all freight processing procedures.

Other measures implemented under the Act relate to increasing the competitiveness of Polish sea ports, including:

1. digitization of applications, i.e. it is no longer necessary to physically inspect the freight, resulting in processing times of between 15 and 40 minutes where the time-limit set by EU standards is 2 hours;

2. curtailed paperwork - documents are accepted in electronic form (eAttachments)

3. pre-arrival clearance - freight is declared for customs clearance before its arrival at the port, which shortens processing times

4. certificate of origin - makes it easier to obtain approvals for exported goods, curbing paperwork and reducing the number of bureaucratic steps and the time needed for carriers and authorities to complete formalities (authorized exporter, registered exporter, in blanco certificates).

5. VAT - VAT deferment on terms similar to those applied in German ports, but limited to AEO holders and enterprises applying simplified procedures

6. export procedure - extends export procedure to goods, refers to EU goods exported out of EU or to special tax areas.

\section{Effects of the reform}

It was in 2017, two years after the new regulations had entered into force obliging the Customs Service to coordinate inspections, National Treasury Administration (NTA) was appointed. NTA was supposed to optimize and coordinate the activities of three authorities: the Customs Service, the Treasury Audit Authority and Tax Administration. NTA was tasked to actively support enterprises and systematically raise standards of service through applying and extending the range of available conveniences and shortening processing times. The reformed Customs Service operating within the new structure as part of NTA holds a respectable place the World Bank's "Doing Business 2018" ranking which describes and compares the conditions of running a business in 190 countries. Polish solutions related to the trade of goods with foreign countries with respect to customs services at border checkpoints came first in a tie against a number of countries [11] (10. The short time and low costs of export and import-related logistical process were particularly applauded).

The port of Gdańsk is undeniably an excellent example of a spectacular success - a record volume of cargo-handling operations amounting to 40.6 million tons in 2017 - only 2 years after the entry of regulations. From the example of the port of Gdańsk, it can be said that only 2 years after the entry into force of the new regulations, a spectacular success was recorded - a record volume.

Table 3. Budget receipts from goods passing through DCT

\section{Budget receipts from goods passing through DCT}

\section{5}

\begin{tabular}{c||c||c||c||c|} 
VAT & 4583 & 5406 & & \\
\hline \hline excise duty & 191 & 4 & & \\
\hline \hline customs duties & 670 & 789 & & \\
\hline \hline TOTAL (mln zł) & 5444 & 6199 & 22500 & 2100 \\
\hline \hline
\end{tabular}

Source: PGA SA based on the data of the Customs Chamber in Warsaw 
and the Statistical Compendium of the Customs Service

The port authority's plan for 2017 projected a throughput of 38.9 million tons, which was in itself an ambitious goal, compared to 2016 when the figure stood at 37 million tons. Such good performance was due to the growth of Deepwater Container Terminal DCT [12], which handled 1.6 million containers, 22 per cent up against the previous year's result; also, thanks to an increase in automotive transports from 14 thousand in 2016 to 74 thousand, marking a radical 412 per cent growth. General mass cargo formed nearly half (44 per cent) of all containerized freights. There was a minimal ( 0.05 per cent) rise in the volume of coal, which accounts for 12.5 per cent of cargo-handling operations. It is assumed that, with a good economic situation, the year 2018 could bring another record, exceeding 50 million tons of handled cargo, with DCT set to service 2 million containers. Despite the successes, there still remains a weak link in the chain, and that is a small share of food transports in the overall cargo traffic through Polish ports, most of which arrives in our country through Rotterdam.

The ports of Gdańsk and Gdynia are the gateway into Poland for 60 per cent of total imports into our country from China. A 19-percent rise in the volume of containerized cargo volume passing through Gdańsk and Gdynia, as compared with the year 2016, was achieved thanks to fast and smooth customs procedures. The container terminal at the port of Gdańsk delivers the bulk of tax contributions.

Table 1. Participation of the Port of Gdańsk in receipts from customs duties, VAT and excise duty from goods handled at the Port of Gdansk

\begin{tabular}{c||c||c||c} 
Year & $\begin{array}{c}\text { In the income of the state } \\
\text { Inflows } \\
\text { in } \\
\text { millions } \\
\text { of PLN }\end{array}$ & $\begin{array}{c}\text { Polish } \\
\text { revenues in } \\
\text { millions of } \\
\text { PLN }\end{array}$ & $\begin{array}{c}\text { The port's share in } \\
\text { the State's revenues }\end{array}$ \\
\hline 2008 & 2223 & 253547 & $0,90 \%$ \\
\hline \hline 2009 & 3035 & 274184 & $1,10 \%$ \\
\hline \hline 2010 & 3758 & 250303 & $1,50 \%$ \\
\hline 2011 & 6479 & 277568 & $2,30 \%$ \\
\hline 2012 & 6264 & 287595 & $2,20 \%$ \\
\hline \hline 2013 & 970 & 279151 & $5,00 \%$ \\
\hline \hline 2014 & 001 & 283543 & $6,00 \%$ \\
\hline \hline 2015 & 400 & 289137 & $6,00 \%$ \\
\hline \hline
\end{tabular}

Source: PGA SA based on the data of the Customs Chamber in Warsaw and the Statistical Compendium of the Customs Service

Table 2. Participation of the Port of Gdańsk in receipts from customs duties, VAT and excise duty from goods handled at the Port of Gdansk

In total revenues for Poland from customs duty, VAT and excise tax

\begin{tabular}{c|cc||c} 
Year & $\begin{array}{c}\text { Polish } \\
\text { customs } \\
\text { offices (PLN } \\
\text { million)) }\end{array}$ & $\begin{array}{c}\text { Customs } \\
\text { branches Port } \\
\text { (PLN million) }\end{array}$ & $\begin{array}{c}\text { Participation of } \\
\text { Gdańsk }\end{array}$ \\
\hline 2008 & 78557 & 2223 & $3 \%$ \\
\hline
\end{tabular}




\begin{tabular}{c||c||c|c}
\hline 2009 & 75880 & 3035 & $4 \%$ \\
\hline \hline 2010 & 80375 & 3758 & $5 \%$ \\
\hline \hline 2011 & 88962 & 6479 & $7 \%$ \\
\hline \hline 2012 & 91272 & 6264 & $7 \%$ \\
\hline \hline 2013 & 83414 & 13970 & $17 \%$ \\
\hline \hline 2014 & 84225 & 16001 & $19 \%$ \\
\hline \hline 2015 & 76835 & 18400 & $24 \%$
\end{tabular}

Source: PGA SA based on the data of the Customs Chamber in Warsaw and the Statistical Compendium of the Customs Service

According to NTA data for 2017, the amount of VAT, duty and excise fees totalled PLN 22.5 billion. The statistical value of goods handled was estimated at PLN 77.5 billion. It is estimated that sea ports account for 6 per cent of the GDP.

It is also responsible for 40 per cent of state treasury revenue. In the first quarter of 2018, the cargo handled at DCT contributed PLN 2.1 billion in duties, VAT and excises.

As a result, Polish sea ports are becoming increasingly competitive against western ones in terms of the time of customs procedures. This could bring an increase in traffic through the port and inthe cargo handled. In all ports, the customs clearance is in electronic form, with most freights not even required to physically undergo inspection. This goes to show that legislative modifications and the smooth operation of public administrative bodies have a large impact on the competitive position of sea ports especially relative to ports in Germany and other Western European countries.

Every third container is cleared under the notification procedure for goods and customs clearance when the cargo is still on board the ship. Physical inspections are becoming more of a rarity where manual checks are used as a supplementary measure. Increasingly, risk analysis is based and relies heavily on electronic data.

\section{Conclusion}

The object of the article was to show that amendments to the law to deregulate and simplify procedures have contributed to the increase of containerized cargo volume in Poland, which means development and a better competitive position for Polish sea ports.

The "Ports $24 \mathrm{~h}$ " programme, in force for 3.5 years now, has been successful and has simplified inspection procedures. The implementation of the Act on Facilitating Business Activities was acclaimed by businesses in the port industry. The clearance of cargo is supervised by the Customs Service which coordinates between all other authorities.

The amended and simplified sanitary, customs and taxation procedures have helped to procure some cargo, handled before by Western ports, mainly in Hamburg and Rotterdam.

The organizational and legal reforms have helped to significantly increase the capacity of Polish sea ports. As a result, these ports will go on to play an increasingly paramount role for the Polish economy and logistics. A further growth in the volume of handled cargo will fall into step with investments into infrastructure. Such tendencies will evidently further support and strengthen the international position of Polish sea ports and Poland in the Baltic Sea area. 


\section{References}

1. M. Adamowicz, Legal aspects of seaports in Poland, Maritime Law 32, 160170 (2017) http://journals.pan.pl/dlibra/publication/107759/edition/93420/content

2. Jones Lang LaSalle Report, Polish Container Ports: New directions of development of the logistics market - September 2013, pdf ss; http://www.jll.pl/poland/pl-pl/raport

3. Polish Act on on facilitating business operations; 7 November 2014; Polish Journal of Laws 2014/ 1662.

4. M. Pluciński, Zasady i źródła finansowanie inwestycji infrastrukturalnych $w$ polskich portach morskich - stan obecny, kierunki ewolucji , Logistyka 2, 2195 - 2203 (2011).

5. M. Matczak, Inwestycje infrastrukturalne realizowane $w$ polskich portach morskich jako narzędzie kształtowania ich pozycji konkurencyjnej, [in:] Polska gospodarka morska. Restrukturyzacja. Konkurencyjność. Funkcjonowanie. Rozwój, editor : H. Salmonowicz, (Wyd. Kreos, Szczecin 2010).

6. Directive 2010/65/EU of the European Parliament and of the Council of 20 October 2010 on reporting formalities for ships arriving in and/or departing from ports of the Member States and repealing Directive 2002/6/EC, Official Journal of the European Union, L 283/1, 29.10.2010.

7. P. Morales-Fusco, S. Saurí,A. M. Lekka, I. Karousos, Assessing Customs Performance in the Mediterranean Ports. KPI Selection and Best Practices Identification as Part of the MEDNET Project, Transportation Research Procedia, 18, 374 - 383 (2016), http://www.sciencedirect.com/science/article/pii/S2352146516308043.

8. J. Nawrot, Ship report ing facilitation under EU regulation. The Polish pat ; Maritime Law 33, 75-86 (2017) http://journals.pan.pl/dlibra/publication/118628/edition/103205/content

9. Convention on Facilitation of International Maritime Traffic (FAL Convention), adopted on 9 April 1965, as amended.

10. M. Pluciński, The duration of border control procedures related to the handling of freight transported by means of sea-road transport chains as a component in competitiveness of the polish seaports, Contemporary Economy 8, 59-69 (2017), www.wspolczesnagospodarka.pl

11. The World Bank, Doing Business, Measuring Business Regulations, in categories: Trading across borders, http://www.doingbusiness.org/rankings

12. M. Adamowicz, Deepwather Container Terminal DCT-Genesis and realization of investments, Contemporary Economy 3, 91-108 (2016), www.wspolczesnagospodarka.pl 